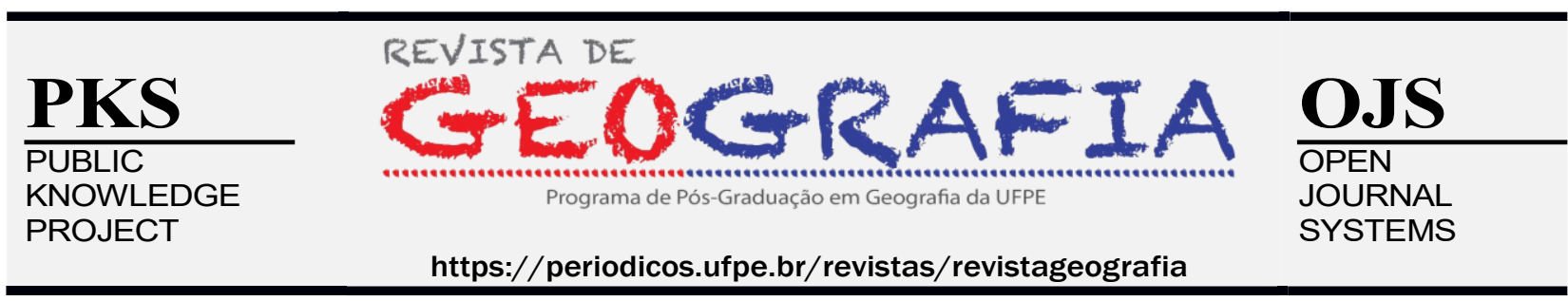

\title{
DIFERENCIAÇÃO SOCIOESPACIAL, VIOLÊNCIA E (IN)JUSTIÇA ESPACIAL NA PERIFERIA URBANA DA TERRA FIRME, BELÉM/PA
}

\author{
Pedro Israel Mota Pinto $^{1}$, Willame de Oliveira Ribeiro ${ }^{2}$
}

\begin{abstract}
${ }^{1}$ Graduando em Geografia pela Universidade do Estado do Pará. E-mail: pedromota777@gmail.com; http://orcid.org/0000-0002-8812-693X
\end{abstract}

${ }^{2}$ Doutor em Geografia, Docente do Programa de Pós-graduação em Geografia da Universidade do Estado do Pará. Email:willame@uepa.br;_http://orcid.org/0000-0003-3692-4224

Artigo recebido em 06/05/2021 e aceito em 12/07/2021

\section{RESUMO}

A violência e a criminalidade nas periferias de Belém-PA apresentam forte relação com a precariedade socioespacial. O objetivo da pesquisa consiste em analisar as diferenciações socioespaciais no bairro da Terra Firme, em Belém do Pará, e suas implicações na ocorrência dos Crimes Violentos, Letais e Intencionais CVLI e na produção de (in)justiças espaciais. A partir de levantamentos bibliográficos, análises documentais e trabalhos de campo constatou-se que a desigualdade socioespacial é marcante no bairro, assinalada pelos aglomerados subnormais, cotas de altimetria e proximidades com instituições públicas. Ademais, destacam-se a violência e a criminalidade através dos CVLI como expressões de outras precariedades e um fator de reforço a elas.

Palavras-chave: Diferenciação Socioespacial; Violência; (In)justiça Espacial; Periferia Urbana.

\section{SOCIO-SPACE DIFFERENTIATION, VIOLENCE AND SPACE (IN)JUSTICE IN THE URBAN SUBURB OF TERRA FIRME, BELÉM-PA}

\begin{abstract}
Violence and criminality on the suburbs of Belém-PA have a consistent relationship with socio-spatial precariousness. This research aims to analyze the socio-spatial differentiations in the Terra Firme neighborhood, in Belém do Pará, and their implications in the occurrence of Violent, Lethal and Intentional Crimes (CVLI) and in the production of space (in)justice. From bibliographical research, documentary analyzes and fieldwork, it was possible to conclude that socio-spatial inequality is prominent in the neighborhood, marked by subnormal agglomerations, altimetry quotas and proximity to public institutions. Moreover, violence and criminality through CVLI stand out as expressions of other precariousness and a factor that reinforces them.
\end{abstract}

Keywords: Socio-space Differentiation. Violence. Space (In)justice. Urban Suburb. 


\section{INTRODUÇÃO}

Nas cidades contemporâneas, faz-se pertinente analisar a articulação entre a ampliação da complexidade dos processos e relações econômicas, políticas, culturais, entre outras dimensões da vida social, e as dinâmicas de produção do espaço urbano que se revelam e se definem, cada vez mais, mediante a diferenciação socioespacial (SPOSITO, 2012). Essas marcas do processo de urbanização se configuram de forma complexa, refletindo-se na divisão social e territorial do trabalho, deixando suas evidências nas mais diferentes escalas. O bairro da Terra Firme, uma periferia urbana de ocupação antiga no espaço metropolitano de Belém do Pará, compõe esse cenário.

Entende-se que o processo de periferização se instalou na cidade de Belém, incisivamente, a partir do século XVIII, quando as classes que não se encaixavam estética e financeiramente no centro da cidade, não conseguindo lá se manter, começaram a procurar outros espaços, nos quais pudessem sobreviver ao processo vigente. Assim, encaminharam-se para as bordas distantes de Belém, formando alguns dos atuais bairros periféricos (FERREIRA, 1995).

É nesse quadro, marcante no bairro da Terra Firme, que se pretende analisar a complexa questão da violência. Compreende-se, de acordo com a Organização Mundial da Saúde (2002, p. 4), a violência como "o uso intencional da força física ou poder, ameaça ou real, contra si mesmo, outra pessoa, ou contra um grupo ou comunidade, que resulte em ou tenha alta probabilidade de resultado em lesão, morte, dano psicológico ou privação".

No que tange à análise da violência, na Geografia, tradicionalmente preocupada com a espacialização das ocorrências, oportuniza-se aos órgãos de segurança pública vigiar e punir crimes, porém, essa relação tem se demonstrado insuficiente para combater a onda de violência que assola as cidades. Seguindo a linha de raciocínio de Ferreira e Penna (2005), a violência e a criminalidade são fenômenos multidimensionais e multifacetados, fazendo-se necessário um estudo crítico da criminalidade e da violência.

Outrossim, aborda-se o conceito de (in)justiça espacial e sua relação com as variáveis aqui colocadas, utilizando-se das reflexões de Pereira \& Ramalhete (2017), que compreendem por (in)justiça espacial um julgamento das formas de (re)organização do espaço alicerçado em modelos normativos aceitos pela sociedade em contextos temporais e espaciais específicos. Por conseguinte, as injustiças estão associadas à auto-organização da sociedade, socialmente estratificada e com rendimentos diferenciados e às dinâmicas de mercado. 
Segundo Soja (2014), adicionar o espaço à justiça territorializa as suas dimensões social e econômica, potencializando um conceito agregador e uma base para a conjugação de esforços e definição de objetivos. Mas, argumenta também que a questão central, mais do que a redução das desigualdades, assenta-se na afirmação das diferenças e no potencial dos atores (atingidos pela injustiça espacial) para formar alianças capazes de agregar interesses distintos na luta pelo direito à cidade (PEREIRA \& RAMALHETE, 2017). Isto é, no que tange ao processo de investigação sobre os Crimes Violentos Letais Intencionais (CVLI), as dimensões sociais e econômicas aprimoram o entendimento sobre a questão.

Faz-se ainda uma discussão envolvendo os aglomerados subnormais, cotas de altimetria e dados do Instituto Brasileiro de Geografia e Estatística para corroborar com a leitura da relação entre as (in)justiças espaciais e a realidade socioespacial no bairro. Estas configurações dão concretude à morfologia urbana periférica encontrada na Terra Firme.

A pesquisa tem como objetivo geral analisar as diferenciações socioespaciais no bairro da Terra Firme, em Belém do Pará, e suas implicações na ocorrência dos Crimes Violentos, Letais e Intencionais - CVLI e na produção de (in)justiças espaciais. Os objetivos específicos são: verificar os principais vetores de diferenciação socioespacial no bairro da Terra Firme; analisar a espacialização dos CVLI no bairro da Terra Firme; e entender a correlação dessa espacialização com o nível de precariedade do espaço e com a diferenciação entre espaços de moradia e de consumo.

Em termos metodológicos, a investigação se caracteriza por utilizar procedimentos inerentes tanto à pesquisa qualitativa quanto à pesquisa quantitativa, coletando e analisando dados secundários, utilizando-se de trabalhos de campo e do mapeamento de informações e dados coletados.

O bairro da Terra Firme, localizado ao sul da metrópole de Belém, foi escolhido para a análise por ser espaço de forte incidência da violência e da criminalidade, bem como por se configurar como espaço precariamente incluído na cidade.

Os seguintes procedimentos metodológicos compuseram a pesquisa:

a) Levantamento bibliográfico - no que se diz respeito aos conceitos e categorias da geografia como produção do espaço urbano, diferenciação socioespacial, violência e injustiça espacial.

b) Levantamento documental - com a utilização de dados do censo demográfico brasileiro de 2010 (IBGE, 2010), expressivos das desigualdades, como aqueles relativos ao saneamento e à configuração dos aglomerados subnormais. Também foram utilizados os dados de Crimes Violentos, Letais e Intencionais - CVLI, coletados junto à Secretaria de Inteligência e Análise Criminal - SIAC, 
integrante da estrutura da Secretaria de Segurança Pública e Defesa Social do Estado do Pará SEGUP/PA.

c) Representações cartográficas dos dados coletados - usou-se o geoprocessamento para mapear as informações e dados levantados, no intuito de facilitar a percepção do leitor e a espacialização das camadas sobrepostas da inclusão precária, correlacionando com a presença intensa da violência.

d) Trabalhos de campo - por meio dos quais foram desenvolvidas atividades diversas, como: contato com sujeitos da pesquisa, observação dirigida, coleta de dados para a produção cartográfica.

O texto está organizado em três partes, sendo elas: 1) apresentação das características periféricas da Terra Firme enquanto bairro da metrópole de Belém; 2) exposição das desigualdades sociais e mazelas da inclusão precária, relativas à morfologia urbano-periférica; 3) a discussão da violência refletida nesse espaço, por meio dos dados de CVLI e da sua espacialização.

\section{CARACTERIZAÇÃO DA TERRA FIRME: AGLOMERADOS SUBNORMAIS E (IN)JUSTIÇA ESPACIAL}

Com base em Corrêa (1986), pode-se entender a periferia como espaço resultante das reproduções dos seus grupos sociais, em sua maioria, de reduzido poder aquisitivo, negros, mães de família, de sexualidades outras e proletariados da metrópole, os quais, por falta de opção, buscam sobreviver e se adequar à realidade periférica e aos seus dramas. Com isso, são conformados locais de reprodução de classes e frações de nichos sociais, traduzindo-se em consciência das desigualdades sócio-político-espaciais (CORRÊA, 1986; SOUZA, 2002; SOUZA, 2003).

O bairro da Terra Firme se harmoniza, em grande medida, com essa caracterização, uma vez sendo resultado das ações dos grupos empobrecidos “expulsos” da área central de Belém. Ele contém uma série de variáveis que materializam sua identidade e também alimentam o estereótipo de periférico, entre elas, a violência e a criminalidade.

Na figura 1, que representa a Terra Firme no contexto da metrópole de Belém, pode-se perceber que o bairro está no centro de um setor formado por outros grandes bairros periféricos e populosos. Articulado por vias relevantes na malha da metrópole, liga-se à parte do Cinturão Institucional formada pela Universidade Federal do Pará, Universidade Federal Rural do Amazônia, EMBRAPA e Centro de Pesquisa do Museu Emílio Goeldi. 
FIGURA 1 - BELÉM. LOCALIZAÇÃO DO BAIRRO DA TERRA FIRME. 2021

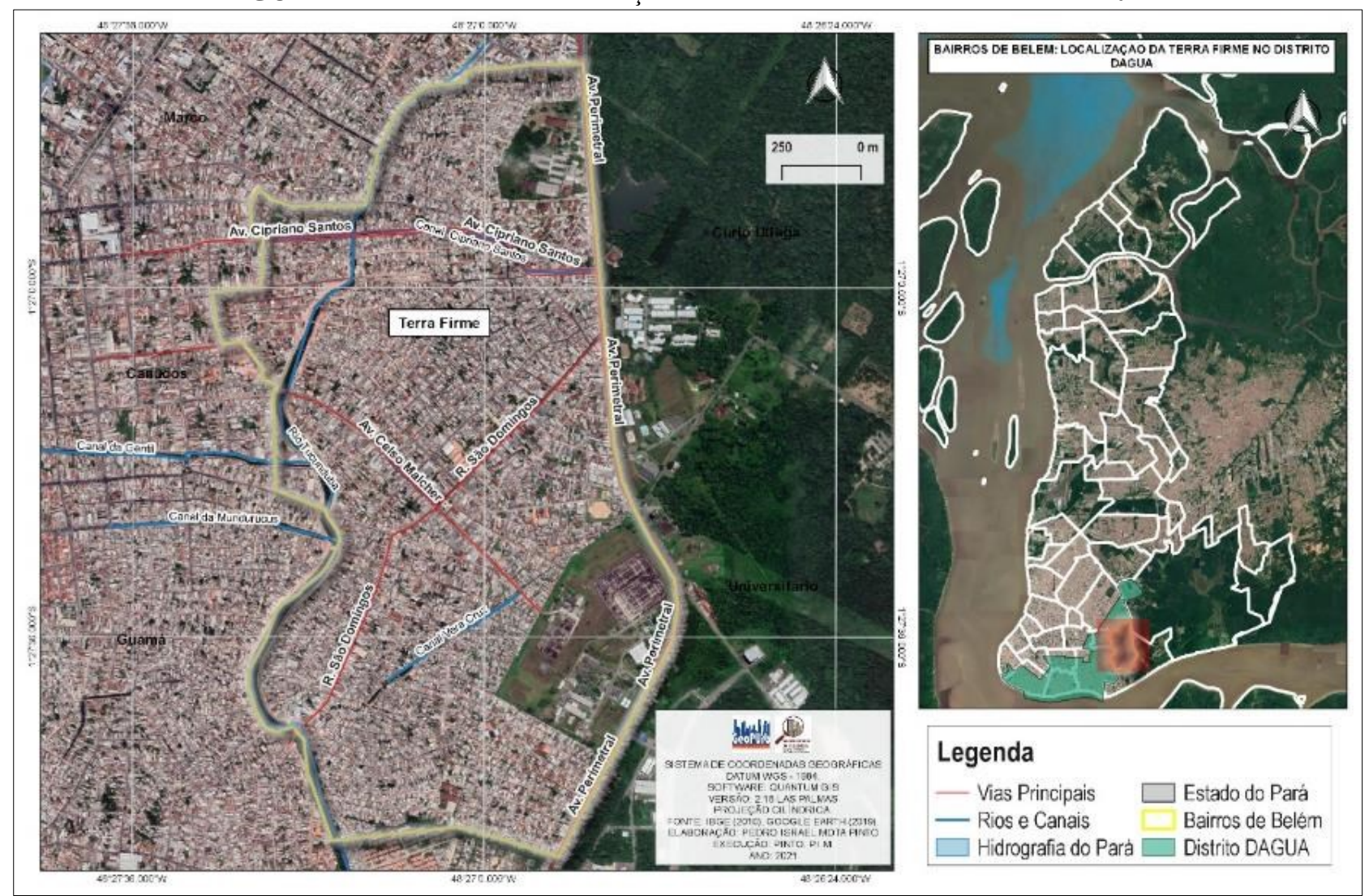

Fonte: Elaboração própria

Conforme Trindade Jr (1998), o processo de metropolização de Belém só pode ser compreendido ao se ter em conta a produção do espaço regional amazônico como fronteira econômica do capital no espaço brasileiro. Isto é, as consequências da importância de Belém no cenário econômico geraram a reestruturação espacial, resultando no processo de produção de espaços periféricos (RIBEIRO, 2016). O mesmo autor ainda destaca que esses espaços se transformaram, durante certo período, em "cidades dormitórios", isto é, espaços de moradia para a população de baixa renda, gerando o movimento pendular dos moradores destes espaços para a área central de Belém, entre a casa e o trabalho.

Em decorrência desse processo, o bairro da Terra Firme se configura como um dos mais populosos da capital. Ademais, recebe esse nome por ser formado por terras firmes e altas em pontos estratégicos, paralelos às áreas alagadas pelo rio Tucunduba no limite dos bairros de Canudos e do Guamá. Conseguiu, assim, gerar a sua própria dinâmica no espaço-tempo, através da economia, cultura e comunidade, todavia convivendo com a precariedade e a criminalidade.

O bairro dispõe de uma área total de 2,2km², porém, $1,9 \mathrm{~km}^{2}$ são de áreas de aglomerados subnormais (figura 2), comportando 95\% de toda a extensão territorial (IBGE, 2010), subdivididos 
em quatro: Perimetral, Bacia do Tucunduba, Parque Amazônia e Eletronorte, conforme o senso demográfico brasileiro de 2010 (IBGE, 2010). O aglomerado da bacia do Tucunduba, região dividida pela parte central do bairro, é o de maior extensão.

Dessa forma, estas áreas de aglomerados subnormais são importantes para a compreensão da diferenciação e das injustiças espaciais no bairro. Estes aglomerados se configuram como formas de ocupação irregular de terrenos públicos ou privados para fins de habitação em áreas urbanas e, em geral, caracterizados por um padrão urbanístico irregular, carência de serviços públicos essenciais e localização em áreas com restrição à ocupação (IBGE, 2019).

Nestes espaços, observa-se a ausência de equidade no acesso a bens e serviços urbanos proporcionados pela metrópole. A acessibilidade às redes de infraestrutura e aos serviços urbanos é desigual mesmo ao se comparar os aglomerados do mesmo bairro da Terra Firme.

A justiça espacial, considerando a acessibilidade à infraestrutura, equipamentos urbanos e os serviços essenciais, não é garantida para as áreas mais afastadas das zonas de relevo elevado, do centro ou de instituições públicas, revelando uma ação técnica e estrutural de naturalização das desigualdades sociais e, assim, de negação real do direito à cidade para essa população, visto que as condições de vida destes indivíduos são desiguais espacialmente, implicando em suas realidades sociais e econômicas. 
FIGURA 2 - TERRA FIRME. AGLOMERADOS SUBNORMAIS. 2010

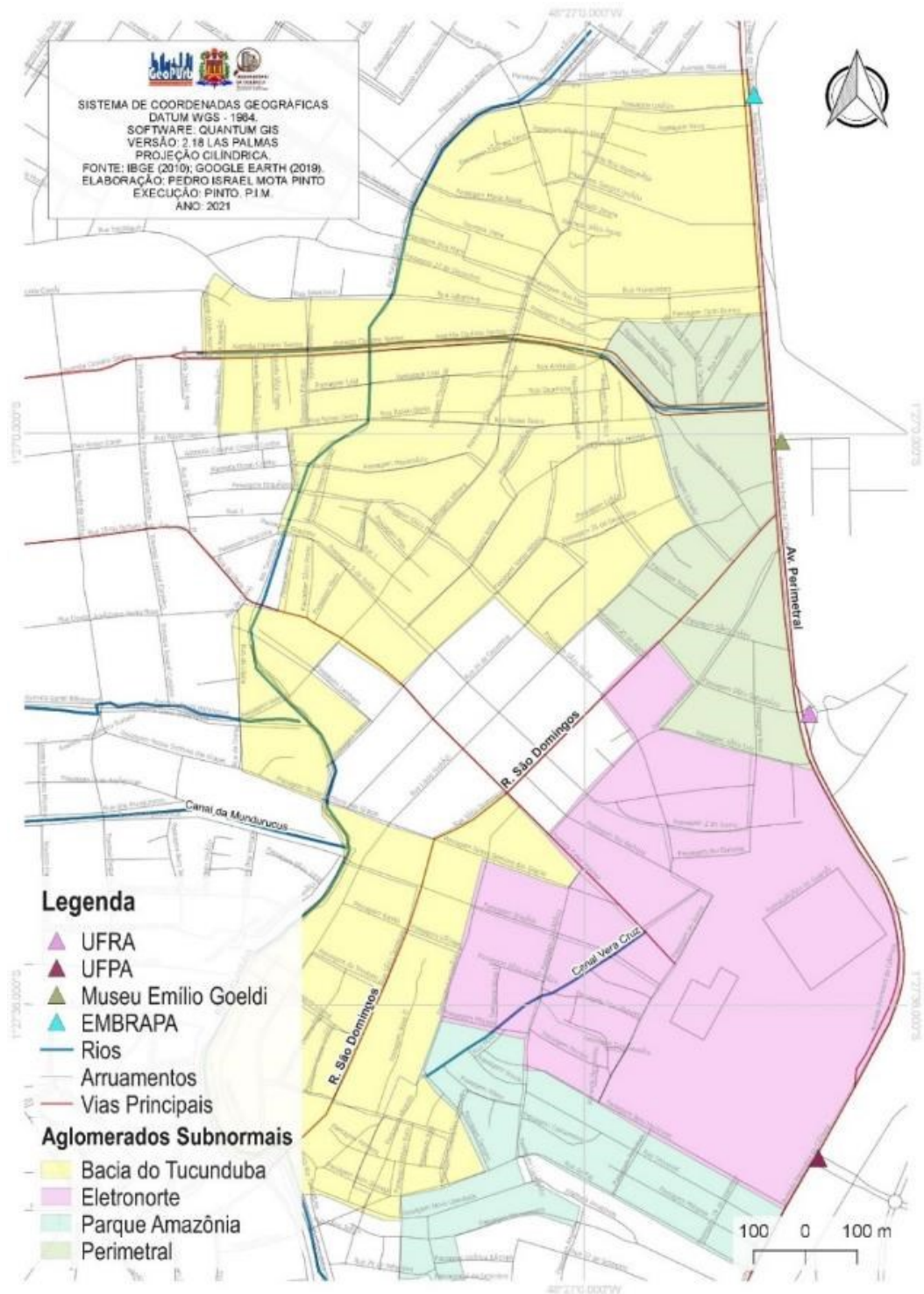

Fonte: IBGE (2010). Elaboração própria (2021).

Ao mesmo tempo em que abriga um grande contingente de população de baixa renda de Belém e sofre com carência de serviços básicos, como o saneamento e a segurança, a Terra Firme concentra várias instituições de pesquisa e ensino (EMBRAPA, Centro de Pesquisa Museu Emílio Goeldi, Universidade Rural da Amazônia e Universidade Federal do Estado do Pará), todas elas de grande relevância social no espaço metropolitano.

A figura 3 identifica a Avenida Perimetral, que assinala o Cinturão Institucional, bem com as travessas e ruas que configuram essa área. O aglomerado da Perimetral, além dos órgãos institucionais, comporta o fluxo de caminhões a caminho dos portos e também populacional, vinculado às instituições e aos bairros da Terra Firme, Guamá e Condor, entre outros que são facilitados por esta avenida. 


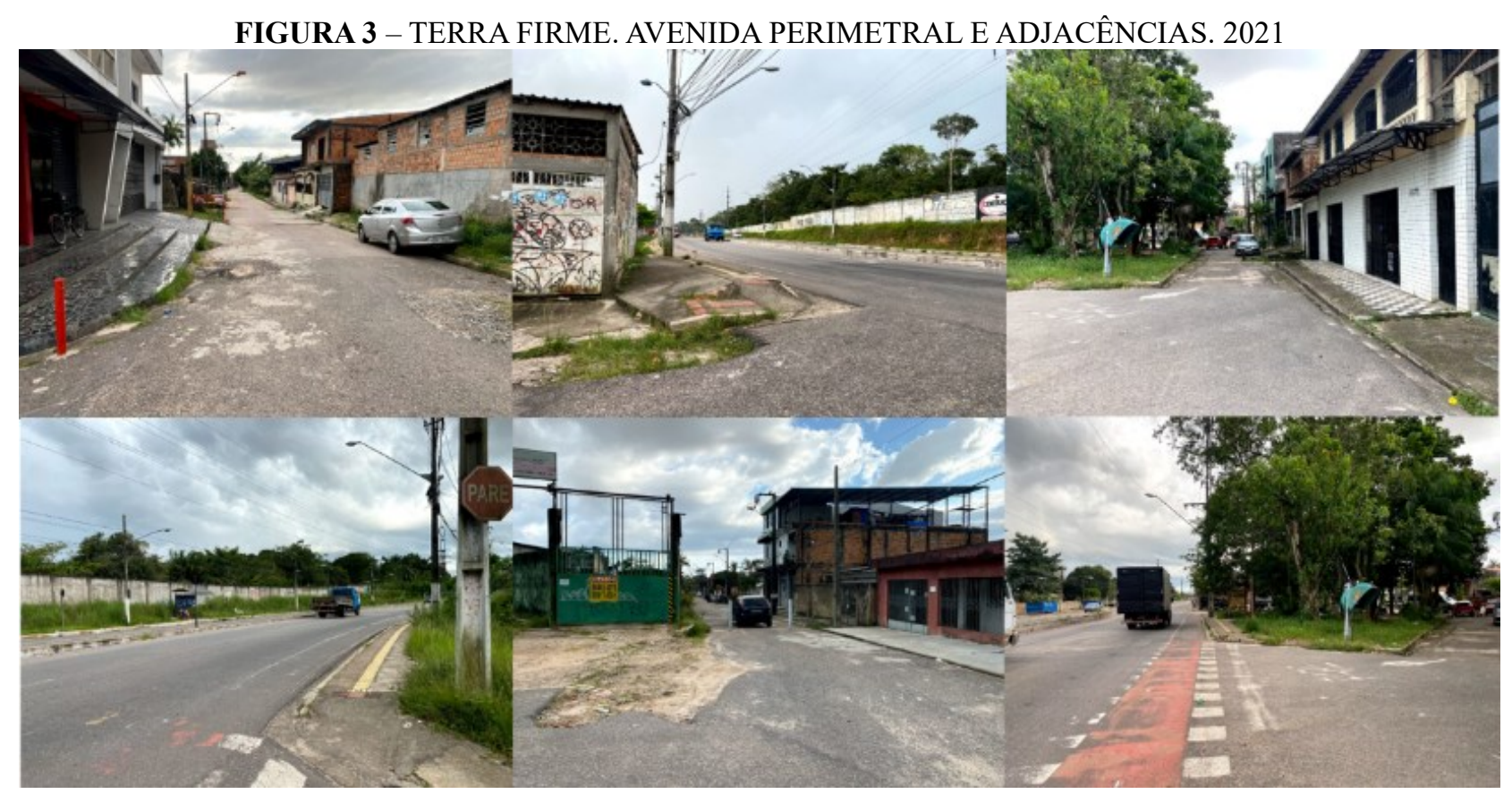

Fonte: Trabalho de Campo (2021).

Posteriormente, é perceptível o asfaltamento regular da Avenida e irregular das ruas ramificadas. Não muito distante do Cinturão Institucional, as desigualdades socioespaciais já surgem no processo de urbanização de áreas importantes em detrimento de áreas menos valorizadas. No que tange a esse processo, a Avenida Perimetral se destaca, além de se localizar em zonas de alta altimetria, também se faz essencial para o fluxo populacional e empresarial da metrópole.

Ademais, faz-se importante mencionar que estas instituições, que compõem o Cinturão Institucional, perpassam pelos quatro aglomerados do bairro. Na zona leste da Terra Firme, como expõe a figura 2, as grandes instituições públicas, que demandam fácil acesso, estão situadas na Avenida Perimetral, responsável por viabilizar os fluxos de todo o espaço metropolitano para estas instituições. O fato desses órgãos se localizarem em área de relevo mais alto corrobora para que este espaço, em específico, conte com a manutenção regular do asfalto e apresente áreas que foram exclusivamente destinadas à habitação, como será apontado nos próximos tópicos.

A Terra Firme também comporta equipamentos urbanos que tentam facilitar a moradia e o habitar da comunidade, possuindo seis escolas estaduais públicas; quatro unidades de saúde pública, distribuídas pelo centro da Terra Firme e no aglomerado da Perimetral; quatro praças públicas; e uma Unidade de Integração Pró Paz, implementada no ano de 2011, localizada no aglomerado da Eletronorte, promovendo projetos sociais para o bairro desde então. 
A periferia também conta com um grande quantitativo de Associações, cinco com o nome propriamente dito, e outras com teor religioso e educacional, que contribuíram para a formação e consolidação das casas e da própria forma da comunidade, além de inúmeros movimentos sociais, que tratam de questões como o racismo, a educação popular e o feminismo. A Terra Firme é conectada com o restante da metrópole de Belém por quatro linhas de ônibus (323, 323 II, 326 e 328), fomentando o tráfego dos moradores do bairro para os grandes centros comerciais da cidade.

\section{O BAIRRO DA TERRA FIRME E AS DIFERENCIAÇÕES SOCIOESPACIAIS}

Para a compreensão da dinâmica das transformações espaciais, é necessário analisar a forma a partir dos processos históricos, sociais, políticos e econômicos da sociedade analisada. Segundo Holanda et al (2000), falar em forma urbana significa remeter à abordagem dos processos de organização social na cidade em consonância com as configurações-configurativas que caracterizam essa região (HOLANDA et al., 2000).

Ainda segundo estes autores, a forma urbana deve ser compreendida a partir de duas qualidades. A primeira seria a material, constituída pela matéria que compõe a cidade, a segunda seria a qualidade cognitiva, remetendo à construção do corpo. Isto é, trabalhar a forma urbana, ou espaço urbano, conduz, assim, à abordagem dos processos de organização social na cidade a partir de suas características configurativas, que constroem esse espaço material através das ações dos corpos inseridos ali (HOLANDA et al., 2000).

Seguindo essa linha de raciocínio, a formação do bairro da Terra Firme está envolta de diversos aspectos. Principalmente, pela procura de terras mais firmes, onde não alagasse com as constantes chuvas na região, por conseguinte, também se buscou zonas mais baratas, onde a população mais pobre pudesse solidificar suas famílias. Num segundo momento, tem-se a produção de áreas de comércio através das feiras, mercados e armarinhos, constituindo-se as centralidades do bairro.

Procura-se, assim, bem como em Holanda et al. (2000), estabelecer as relações entre as características configurativas do bairro e aspectos como uso do solo, áreas de moradia e de consumo, distribuição de investimentos urbanos, dinâmica de classes sociais e estratégias das ações associadas à violência e à criminalidade na periferia da Terra Firme.

O bairro foi produzido, num primeiro momento, nas suas zonas mais firmes e altas. De acordo com a altimetria, o centro e a zona leste são as áreas mais propícias à habitação, conforme a 
figura 4, na qual as cotas estão distribuídas a partir do intervalo de 2 metros de altimetria. Ressaltase que $72 \%$ do bairro se faz susceptível à inundação.

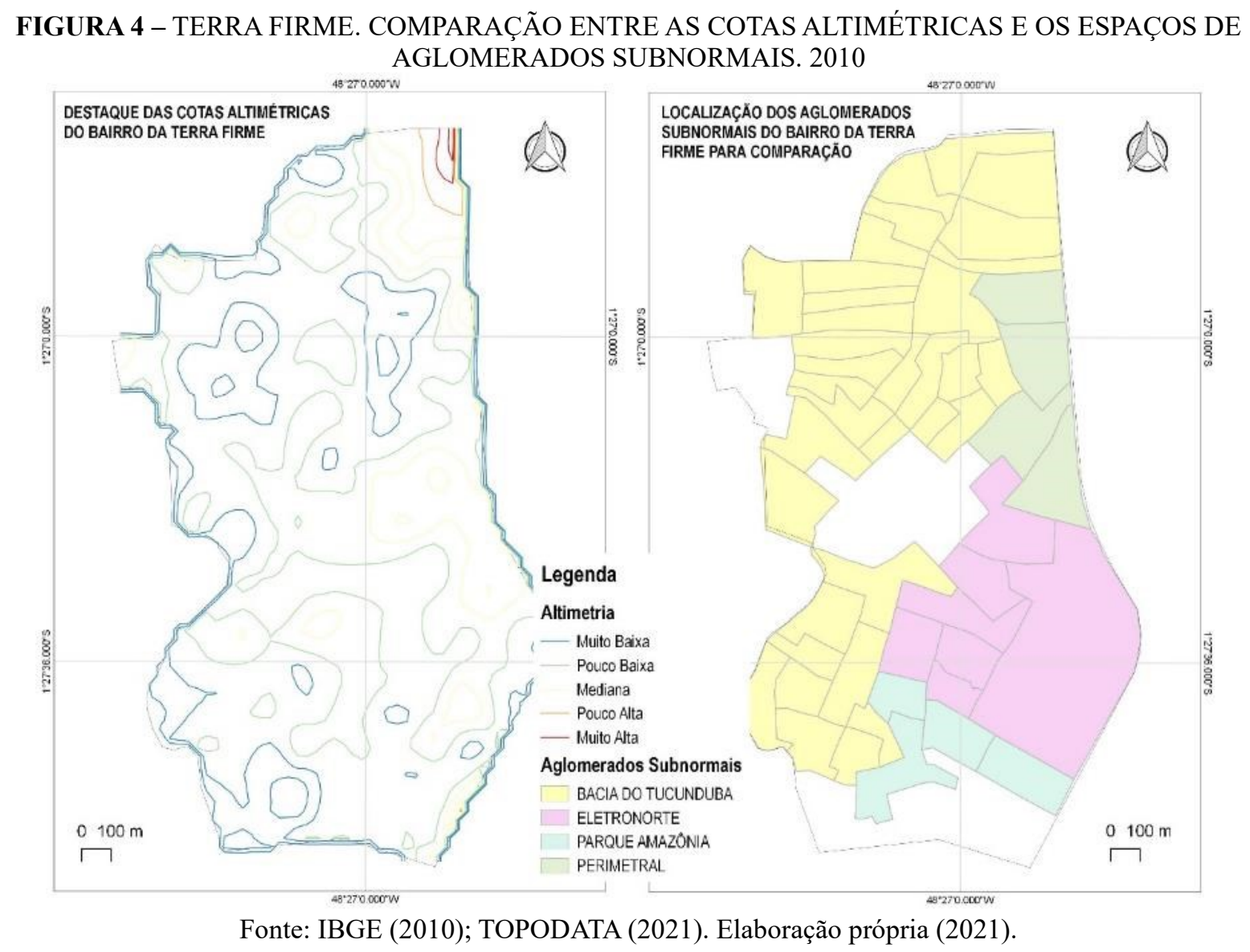

$\mathrm{Na}$ figura 4, pode-se visualizar zonas de cotas medianas, nas quais estão espacializadas as áreas com melhor infraestrutura do bairro. Uma parcela próxima às instituições públicas importantes e a outra nas partes centrais, no aglomerado da bacia do Tucunduba e no centro, que não se configura como aglomerado, onde está boa parte do comércio do bairro. Esses espaços foram primeiramente ocupados para habitação, pertenciam aos poderes federais, e receberam o novo uso por meio da luta por moradia, o que gerou movimentos sociais e associações de bairro (FERREIRA, 1995).

Por conseguinte, através da expansão territorial partindo das cotas medianas, observa-se que, bem mais tarde, as cotas muito ou pouco baixas do bairro foram habitadas, levando mais tempo para que houvesse uma efetiva ação do Estado na promoção de melhorias no saneamento básico e na segurança pública nestas regiões. De acordo com as espacializações representadas cartograficamente a seguir (figuras 5,6 e 7), salienta-se que as propriedades particulares permanentes, iluminação pública e abastecimento de água estão mais concentradas nas cotas medianas e com menor intensidade nas cotas muito baixas e distantes das importantes instituições públicas. 
De acordo com o Instituto Brasileiro de Geografia e Estatística (IBGE, 2010), o Domicílio Particular Permanente (DPP) é o domicílio que foi construído para servir exclusivamente à habitação e, na data de referência, tinha a finalidade de servir de moradia a uma ou mais pessoas. Nessa perspectiva, observa-se, no bairro em questão, a pouca quantidade de áreas separadas exclusivamente para moradia, isto é, a contradição inicial de uma região que foi procurada para tal objetivo pela população mais pobre da cidade (FERREIRA, 1995). Dessa maneira, se analisa que $41 \%$ do bairro da Terra Firme é composto por moradias que não foram designadas para serem DPP.

Entende-se as informações da figura 5 enquanto baixo, médio e alto quantitativo de espaços separados para a moradia, isto é, as áreas do bairro que foram designadas para que se pudesse constituir moradia à população que buscou na periferia um espaço para sobreviver e se reinserir na economia e na sociedade da metrópole. Esse dado expõe que os $41 \%$ do bairro não foram permitidos à habitação, foram conquistadas através da luta comunitária dessa comunidade, como consta em Ferreira (1995). 
FIGURA 5 - TERRA FIRME. IDENTIFICAÇÃO DAS ÁREAS EXCLUSIVAMENTE SEPARADAS PARA A HABITAÇÃO. 2010

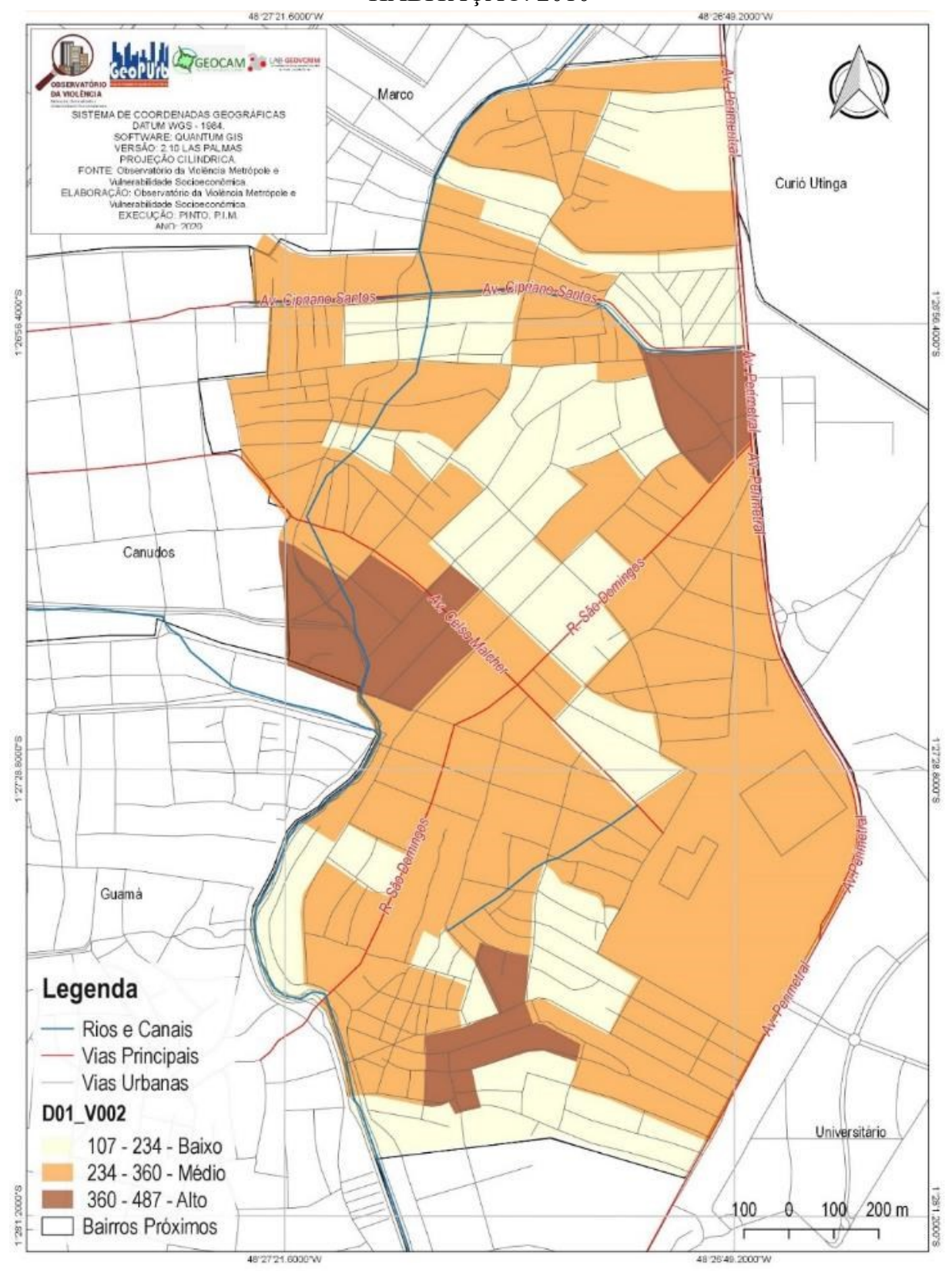

Fonte: IBGE (2010). Elaborado pelo Observatório da Violência (2020).

Além disso, essa separação pouco privilegia os moradores que se instalaram nos espaços das instituições públicas, visto que muitas delas se encontram nas Cotas Muito Baixa, destacados na figura 4, nos aglomerados do Parque Amazônia e na bacia do Tucunduba. Como exposto no gráfico 1, apenas $7 \%$ da Terra Firme foi preparada para a moradia, toda a forma do bairro posterior a isso foi construída de forma precária. 


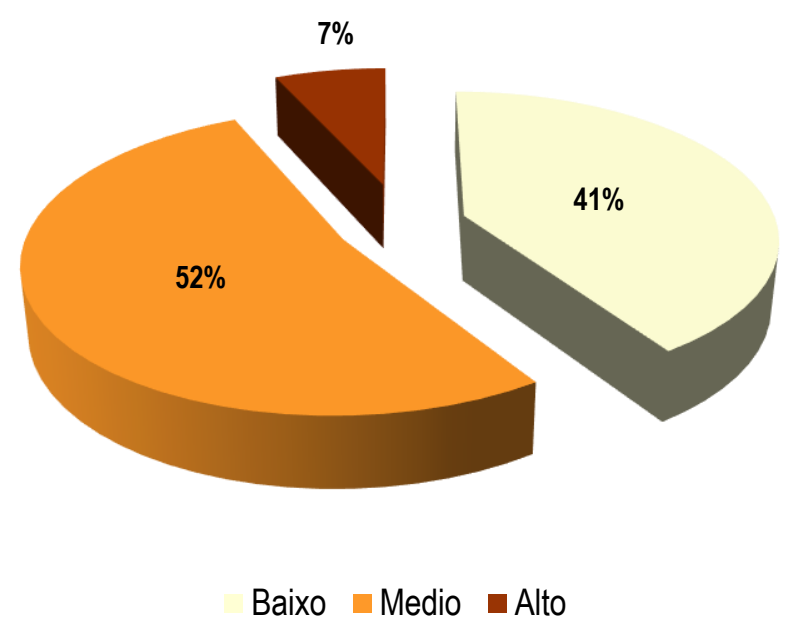

Fonte: IBGE (2010). Elaborado pelo Observatório da Violência (2020).

De acordo com a análise do gráfico 1, existe uma diferença de $34 \%$ entre o nível alto e o nível baixo de DPP's. As maiores intensidades de Domicílios Permanentes Particulares estão nas áreas de loteamentos residenciais, sendo as primeiras ocupações oficiais do bairro, e as de baixa intensidade se encontram em áreas de mais recente ocupação ou de densa área de consumo dominadas por estâncias (lojas de material de construção).

Seguindo a mesma lógica, foram elaboradas mais duas produções cartográficas que corroboram com a perspectiva já discutida acerca da inclusão precária do bairro, no que se refere à equidade social, agora, considerando a presença ou não de serviços públicos básicos, como a iluminação pública e o abastecimento de água potável na Terra Firme.

$\mathrm{Na}$ figura 6, observa-se a presença da iluminação pública pela periferia, dividida em baixa, média e alta implementação deste direito público, indispensável ao uso do espaço com segurança, tendo em conta tanto a possibilidade de acidentes de tráfego, quanto as facilidades das práticas criminosas e de expansão da violência. A presença do serviço se demonstra um privilégio no que tange ao espaço estudado, visto que somente pontos específicos do bairro dispõem de alta presença de iluminação. 
FIGURA 6 - TERRA FIRME. EXISTÊNCIA DE ILUMINAÇÃO PÚBLICA. 2010

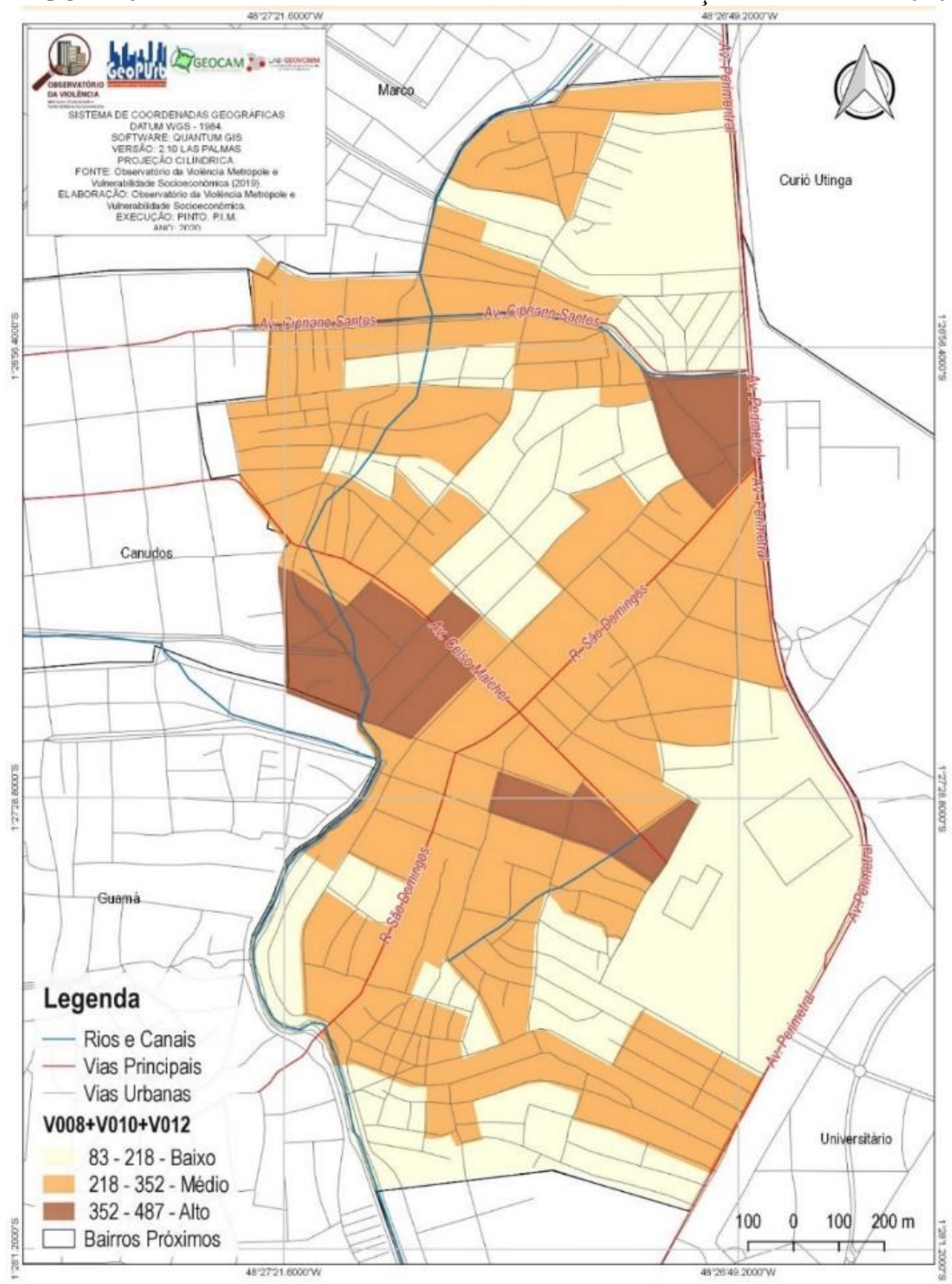

Fonte: IBGE (2010). Elaborado pelo Observatório da Violência (2020).

A Constituição Federal de 1988 (BRASIL, 2013) definiu que a iluminação pública é de responsabilidade do município, possibilitando a instituição da Contribuição de Iluminação Pública (CIP), que, por sua vez, pode ser arrecadada por meio da fatura de energia elétrica. Isto é, o poder público municipal tem por obrigação garantir o serviço, indispensável à continuidade da urbanização, em contrapartida, a falta dele pode ocasionar a intensificação da criminalidade e prejudicar a população que trabalha ou estuda à noite. Em periferias como a Terra Firme a questão se faz mais necessária, visto que o bairro conta com o funcionamento de duas grandes feiras que começam as suas atividades na madrugada e precisam da iluminação para viabilização do trabalho. 
Ademais, observa-se que as áreas com mais intensidade de iluminação pública estão na parte central dos aglomerados da bacia do Tucunduba, próximo a sua via principal, nessa mesma lógica, também na centralidade do aglomerado da Perimetral e, por fim, nos aglomerados da Eletronorte, explicando-se pela presença da própria Eletronorte, que faz parte do Cinturão Institucional.

Em contrapartida, as áreas com baixo índice de Iluminação Pública se encontram em zonas de recente ocupação, com forte presença das áreas alagadiças que prejudicam o bem-estar social dos moradores desses espaços. A falta da iluminação aumenta a insegurança, principalmente em espaços que não contém algum tipo de concentração (espaços de consumo, creches, escolas, praças). As áreas escuras, com facilidade a atos ilícitos, dificultam o direito de ir e vir do cidadão. Por fim, apenas 52\% da Terra Firme é agraciada medianamente com a variável exposta.

Após se realçar a escassez da distribuição da iluminação pública no bairro, constata-se que, nesta periferia, um bem tão simples como a oportunidade de ir e vir no turno da noite é de acesso a poucos. Essa problemática termina no cerceamento dessa população, ao restringir tanto o uso do espaço à noite, quanto favorecer a violência, ao permitir que noturnamente a criminalidade possa se territorializar no bairro, afim de produzir pontos de comércio de drogas e pontos de encontro para acertos de conta e reprodução dos CVLI expostos mais à frente.

Outro dado considerado na análise foi o abastecimento de água. A implantação ou melhoria dos serviços de abastecimento de água traz como resultado uma rápida e sensível melhoria na saúde e nas condições de vida de uma comunidade, principalmente através do controle e prevenção de doenças e da melhoria da limpeza pública. Reflete também no estabelecimento de meios que importam em melhoria do conforto e da segurança coletiva, além disso, constitui o melhor investimento em benefício da saúde pública. Nesse sentido, analisou-se a questão do abastecimento de água no bairro da Terra Firme (figura 7). 
FIGURA 7 - TERRA FIRME. IDENTIFICAÇÃO DOS DPP'S - COM ABASTECIMENTO DE ÁGUA DA

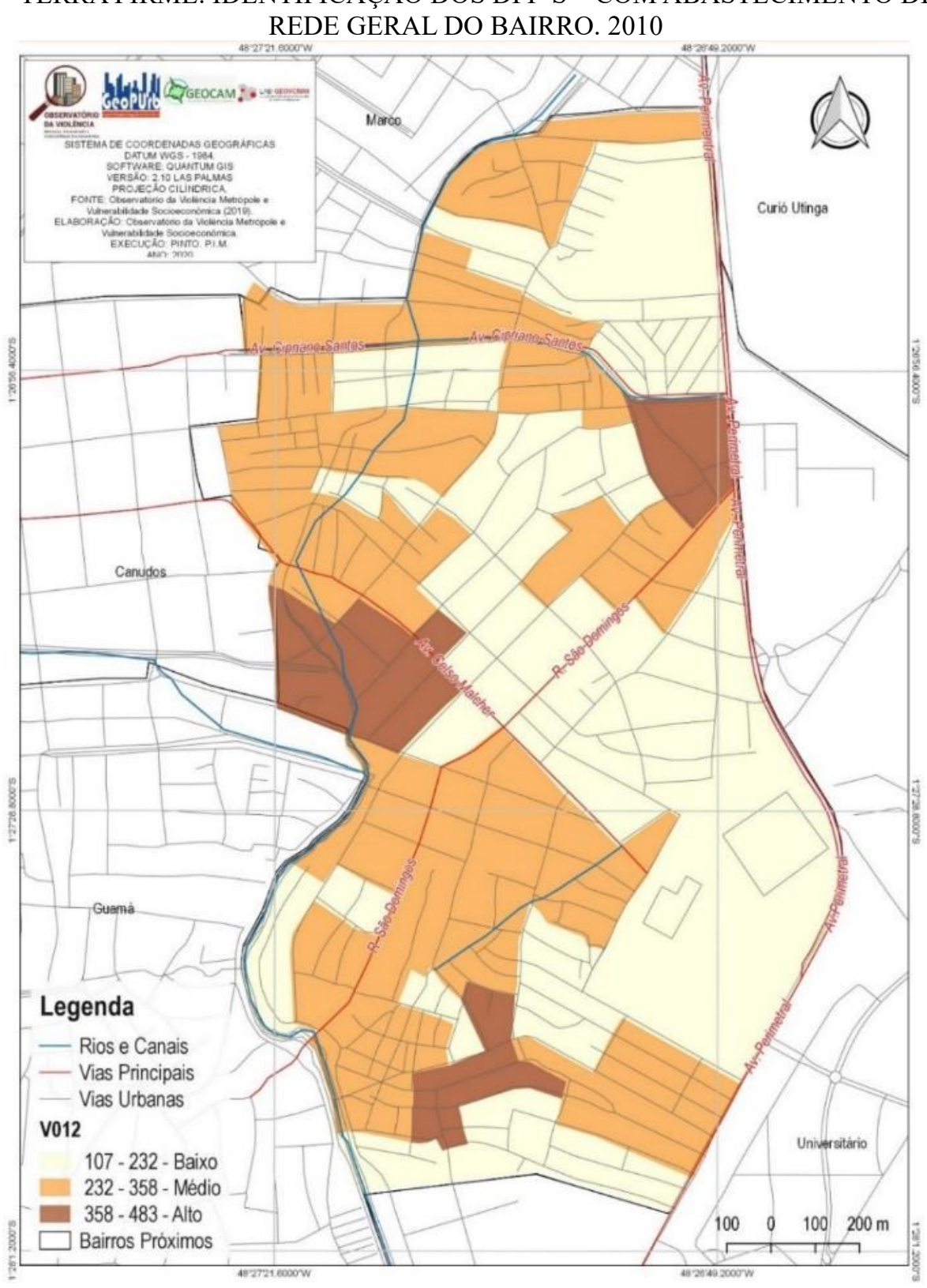

Fonte: IBGE (2010). Elaborado pelo Observatório da Violência (2020).

No que tange a essa variável, observou-se a carência do abastecimento de água pela rede geral em $49 \%$ do bairro. Na mesma lógica dos fatores já tratados, essa distribuição se dá de maneira seletiva e desigual, privilegiando espaços das primeiras ocupações designadas à moradia em detrimento das recentes ocupações e baixadas.

Além disso, a média desse abastecimento, de $44 \%$, se encontra em espaços de moradia próximos a outros bairros também populosos e periféricos, como o Marco, Canudos e Guamá, seguindo o fluxo do rio Tucunduba e canais. Em detrimento das zonas de baixo abastecimento de 
água pela Rede Geral, que se aproximam mais de bairros sem uso majoritário de moradia, sendo eles o bairro do Curió-Utinga e do Universitário.

\section{A VIOLÊNCIA E A CRIMINALIDADE COMO CONDICIONADAS/CONDICIONANTES DO ESPAÇO PERIFÉRICO}

A compreensão que embasa este tópico é a de que a precariedade da Terra Firme, exemplificada nos fatores analisados no item anterior (domicílios particulares permanentes, iluminação pública e abastecimento de água) atua como condicionante da violência e da criminalidade, não o único, mas um importante fator a condicioná-las, favorecendo a sua reprodução. Ao mesmo tempo, a precariedade do bairro, de caráter socioespacial, é condicionada pela violência e pela criminalidade, que atuam como vetores de aprofundamento dos dramas sociais vivenciados na periferia.

O bairro da Terra Firme, por sua condição de periferia, apresenta uma inclusão precária (MARTINS, 1997) no espaço metropolitano, convivendo com grandes deficiências na oferta de serviços públicos básicos. Martins (1997) argumenta que o termo "excluídos socialmente" se faz inconstante, visto que a exclusão se dá num momento reduzido, entre a exclusão de um grupo social e a inclusão deste mesmo grupo em outro processo econômico, o que o leva à proposição da expressão inclusão precária, como aquela que melhor traduz a participação desfavorável de certos grupos nas dinâmicas próprias da sociedade capitalista.

A periferização, da forma exposta por Ferreira (1995), consiste na reinserção da população mais pobre na cidade através da construção das periferias, neste caso, o bairro da Terra Firme. Desse modo, novamente incluídos no plano econômico do espaço urbano, com uma nova realidade no plano social e moral, como resultado de um processo que cria uma sociedade paralela, incluindo, do ponto de vista econômico, visto a concepção de um bairro gerador de economia, mão de obra e dinâmica econômica própria, e excluindo do ponto de vista social, moral e político (MARTINS, 1997).

Em consonância com Silva (2015), nesse contexto, há ainda outros fatores que podem ser determinantes para o aumento dos CVLI, como: consumo e tráfico de drogas, porte ilegal de armas, matadores de aluguel, milícias de bairro, violência contra o gênero e a reprodução dos crimes de ódio. Sendo o espaço um agente ativo na construção de geografias complexas, (re)produzidas coletivamente e potencializadoras de desigualdades, a injustiça espacial ocorre quando estas materializam discriminações físicas, sociais e econômicas (PEREIRA \& RAMALHETE, 2017), como aquelas que a pesquisa busca entender dentro das variáveis do CVLI na periferia urbana da Terra Firme. 
Neste sentido, o bairro da Terra Firme, comumente chamado de "zona vermelha", para identificar esta mazela referente à criminalidade, é entendido como um gerador desta violência. Quando, de fato, a violência e a criminalidade estão atreladas a um conjunto de fatores, entre eles, o não investimento social, estrutural e infraestrutural. Ressalta-se que o termo "zona vermelha" nasce justamente da ferramenta cartográfica chamada "zonas de calor", que intensifica as áreas mais intensas dos dados processados. Esse processo contribuiu para que, de maneira até estereotipada, a Terra Firme recebesse essa marcação social.

Paralelo a esse processo, o Crime Violento Letal Intencional (CVLI), conceito utilizado nesta pesquisa, é uma categoria agregadora correspondente aos crimes de homicídio doloso, roubo seguido de morte (latrocínio) e lesão corporal seguida de morte, que visa facilitar a identificação e quantificação da violência letal intencional, representando as ações/omissões com violência (AGUIAR \& FERRAZ, 2018). Os CVLI, mapeados posteriormente, correspondentes aos anos de 2014 a 2018, fomentam a marcação de zonas mais intensas de crimes e da criminalidade no bairro.

Esses crimes, como o ato ilícito, expõem um quadro da criminalidade enquanto construção social advinda, entre outros fatores, da falta de oportunidade, das (in)justiças espaciais e da dinâmica do tráfico de drogas, facilitadas no bairro da Terra Firme. Assim como salienta Nascimento et al. (2019), observa-se que o processo de precarização do bairro da Terra Firme, condicionou o surgimento de uma relação de territorialidade do crime em seu respectivo espaço-tempo, expondo que a condição social das relações na periferia é intensificada pela violência, retratada nos índices de CVLI mapeados entre os anos de 2014-2018, na Terra Firme.

Sendo assim, esta análise permite compreender a criminalidade como um conjunto de condutas que se manifestam no espaço, a partir de correlações territoriais impulsionadas por diversos fatores e potencializadas, de acordo com os CVLI, por precariedades nos setores sociais como saúde, educação e segurança pública (NASCIMENTO et al., 2019). Este fato se contextualiza na periferização que o bairro de estudo evidencia, sendo esta a sua característica principal.

A inclusão precária, como bem expõe Martins (1997), reflete nessa perspectiva, quando se salienta que o bairro conta com o seu terreno instável, suscetível a alagamentos; $95 \%$ constituído de aglomerados subnormais; $41 \%$ do bairro composto por moradias que não foram designadas para serem DPP; má distribuição de iluminação pública; 49\% do bairro sofrendo com a carência do abastecimento de água potável (dados já discutidos no texto).

Estes fatores, como expressões da inclusão precária e das injustiças socioespaciais vivenciadas pelos moradores da Terra Firme, influenciam na dinâmica da violência e da criminalidade, 
condicionando-as. O gráfico 2 representa o quantitativo de Crimes Violentos Letais Intencionais, entre os anos de 2014 e 2018, no bairro da Terra Firme, evidenciando essas ocorrências como de grande expressão no bairro e funcionando como um fator de precarização socioespacial, ao mesmo tempo em que sua manifestação também é condicionada por outros aspectos da precariedade.

\section{GRÁFICO 2 - TERRA FIRME. QUANTITATIVO DOS CRIMES VIOLENTOS LETAIS INTENCIONAIS. 2014- 2018}

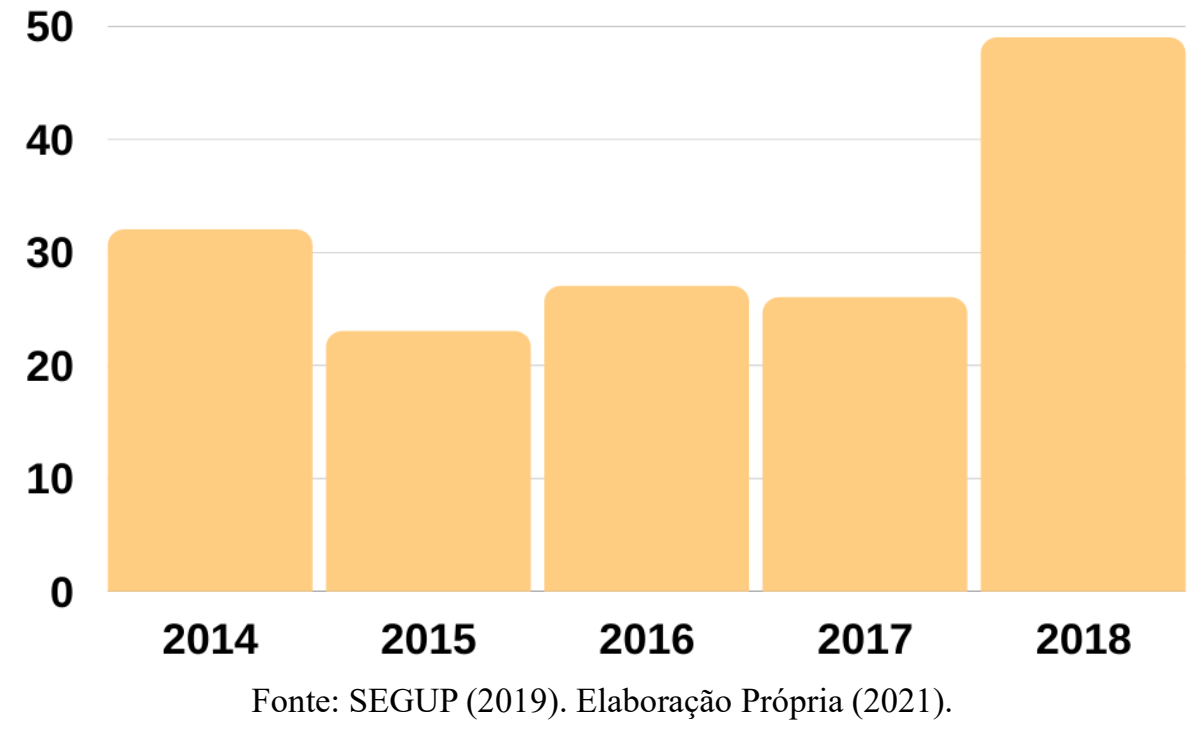

No gráfico 2, pode-se observar que a mortalidade através dos CVLI obteve o maior quantitativo em 2018, chegando a 49 mortes, segundo os dados da Secretaria de Segurança Pública do Estado, seguido por 2014, quando se ultrapassou a marca dos $30 \mathrm{CVLI}$, anos nos quais o bairro ficou marcado por chacinas, através do carro prata, símbolo das milícias que atuam lá e em outras áreas da metrópole, bem como por conflitos entre facções. Isso permite uma reflexão sobre como essa evolução de CVLI se estabelece na Terra Firme, muitas vezes naturalizada pelas mídias sensacionalistas que pregam uma falsa "consequência" do crime refletidas nas estatísticas. Entretanto, a pesquisa em questão expõe que muito além disso se pode inferir desse processo condicionado e condicionante.

Por conseguinte, na figura 8, apresenta-se a espacialização dos dados coletados, expondo onde estão dispostos cada CVLI, sua intensidade e classificação através da tipologia do crime efetuado. Dessa forma, evidencia-se a localização da violência no bairro e o modo como ela se dispõe nos espaços de moradia, de comércio e de lazer. 
FIGURA 8 - BAIRRO DA TERRA FIRME. ESPACIALIZAÇÃO DOS CRIMES VIOLENTOS LETAIS INTENCIONAIS. 2014-2018

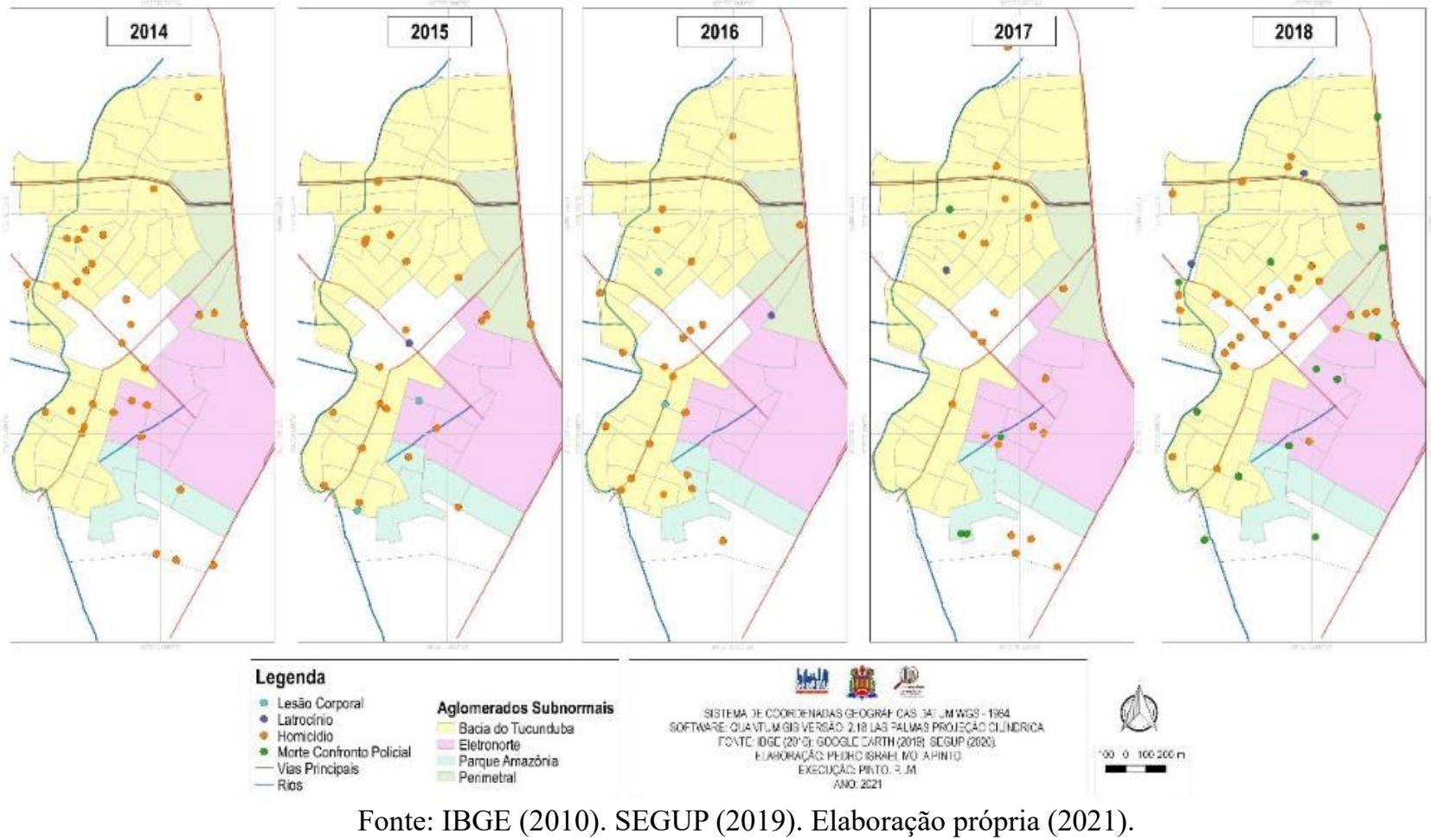

Fica evidente na figura 8, que as áreas comerciais são aquelas com maiores índices de CVLI no ano de 2018, enquanto nos anos anteriores se pode perceber uma maior extensão e espacialização dos crimes em zonas de baixada, proximidades com o rio Tucunduba, pelas vias principais e também na aproximação com o bairro do Guamá, sendo em zonas mais altas quando próximas às vias principais da Perimetral e Celso Malcher. Esse destaque leva à reflexão acerca do que Couto (2014) expõe como a facilidade que a violência e a criminalidade encontram para criar territórios em um bairro dentro do "processo desestruturado de urbanização", sendo ele constituído pela carência de serviços públicos e infraestrutura urbana.

Outrossim, salienta-se também que o crime de maior intensidade é o de homicídio, o assassinato intencional da vítima em questão. Geralmente, este índice se faz pertinente pelo contexto da disputa do tráfico de drogas no bairro, entre facções e milícias, que através do "tribunal do crime", decidem quem morre. Porém, constata-se, conforme a análise dos dados coletados, que nem todas as vítimas dessa linha de fogo eram partícipes desse cenário.

Segundo Corrêa \& Lobo (2019), nos anos de 2013 a 2015, os homicídios convergiram para os bairros considerados mais pobres de Belém, dentre eles, o bairro da Terra Firme. A análise dos autores condiz com a discussão aqui feita acerca das desigualdades sociais e espaciais quanto aos 
bairros periféricos, e como esses fatores corroboram para o aumento dos índices de violência expostos nos dados de CVLI.

É necessário destacar, bem como salienta os estudos de Couto (2014) e Corrêa \& Lobo (2019), que as áreas periféricas de Belém são os espaços propícios ao tráfico de drogas por apresentar condições que favorecem a sua reprodução, como mercados consumidores e pontos de distribuição. Ao mesmo tempo, essas áreas também podem se tornar locais de intensos e inevitáveis conflitos, para reafirmar a sujeição aos códigos previamente estabelecidos pela organização criminosa (CORRÊA \& LOBO, 2019). Sendo eles: acerto de contas, roubo em territórios comandados pelo tráfíco, latrocínio para uso de drogas, violência de gênero, violência de ódio, entre outros.

\section{CONSIDERAÇÕES FINAIS}

Pode-se afirmar, assim como Chagas (2014), que a precarização de bairros da cidade e a histórica precariedade da atuação do poder público, propiciaram o advento de relações que marcam o espaço-tempo por meio da violência. Deve-se advertir, no entanto, que a manifestação da criminalidade nas áreas mais precarizadas, nem de longe, significa que a pobreza gera violência, senão, que a atuação desigual do Estado e as contradições das dinâmicas econômicas podem ocasionar o surgimento de disputas por recursos e localizações interessantes aos agentes territoriais do crime. As cartografias realizadas no presente trabalho refletem que grande parte dos CVLI's ocorrem principalmente nas porções de aglomerados subnormais. Em torno de $80 \%$ desses crimes se apresentam nessas localidades.

Seguindo essa linha de raciocínio, compreende-se também que a maior parte dos CVLI's ocorre em áreas propícias a inundações, nas zonas que constituíram o início do processo de produção e precarização do espaço urbano pela população que buscou na Terra Firme o seu lugar de moradia e habitação. Ademais, de acordo com a faixa altimétrica identificada no bairro, também varia a renda e as ocorrências de CVLI. Isto é, na área central do bairro, que se destaca pelos espaços de consumo, a espacialidade dos Crimes Violentos Letais Intencionais se diferencia daquela das outras áreas, que são majoritariamente referentes à moradia. Sendo assim, os níveis de precariedade e as diferenciações socioespaciais implicam diretamente nas dinâmicas das relações na periferia.

Nessa perspectiva, como em Nascimento (2019), pode-se inferir que inúmeros fatores influenciam nessas dinâmicas, desde a estrutura física do bairro até a própria organização espacial propriamente dita, bem como a precariedade das políticas públicas também implica nas ocorrências de CVLI. 
Desse modo, constatou-se na pesquisa que a violência e a criminalidade, evidenciadas nos CVLI, são condicionadas pelos fatores de precariedade destacados no texto (aglomerados subnormais, cotas de altimetria, desigualdades socioespaciais de iluminação pública, abastecimento de água e marginalização da moradia), reforçando, assim, o cenário violento e de criminalidade encontrado no bairro da Terra Firme, na metrópole de Belém.

\section{REFERÊNCIAS}

AGUiAR, J. M. B.; FERRAZ, V. R. S. Análise Estatística dos Crimes Violentos Letais Intencionais em Teresina, nos anos de 2014 e 2015. 31p. Monografia (Especialização em Estatística). Teresina: Universidade Federal do Piauí, Programa de Pós-Graduação em Estatística, 2018. Disponível em: http://www.pc.pi.gov.br/download/201805/PC23_70adef5cc1.pdf. Acesso em: 10 jan. 2021.

BRASIL. Constituição da República Federativa do Brasil - 1988. Brasília: Senado, 2013. Disponível em: $<$ http://www.senado.gov.br/legislacao/const/con1988/CON1988_05.10.1988/CON1988.pdf>.Acess o: $11 / 08 / 2019$.

CHAGAS, C. A. N. Geografia, segurança pública e a cartografia dos homicídios na Região Metropolitana de Belém. Boletim Amazônico de Geografia, Belém, n. 1, v. 01, p. 186-204, jan./jun. 2014.

CORRÊA, R. L. A Periferia Urbana. Geosul, n. 2, 1986. Disponível em: https://periodicos.ufsc.br/index.php/geosul/article/view/12551/11859. Acesso em: 12 out. 2020.

CORRÊA, R. S. S.; LOBO, M. A. A. Distribuição espacial dos homicídios na cidade de Belém (PA): entre a pobreza/vulnerabilidade social e o tráfico de drogas. URBE. Revista Brasileira de Gestão Urbana, $\quad$ v. 11, e20180126, 2019. Disponível em: https://periodicos.pucpr.br/index.php/Urbe/article/view/25501. Acesso em: 12 nov. 2020.

COUTO, A. C. O. A geografia do crime na metrópole: das redes ilegais a "territorialização perversa" na periferia de Belém. Belém: EDUEPA, 2014.

FERREIRA, C. F. Produção do espaço urbano e degradação ambiental: um estudo sobre a várzea do igarapé do Tucunduba (Belém - PA). 176p. Dissertação (Mestrado em Geografia Física), São Paulo: FFLCH/USP, 1995.

FERREIRA, I. C. B; PENNA, N. A. Território da violência: um olhar geográfico sobre a violência urbana. GEOUSP - Espaço e Tempo, São Paulo, no 18, pp. 155 - 168, 2005. Disponível em: https://www.revistas.usp.br/geousp/article/view/73979. Acesso em: 02 set. 2020.

HOLANDA, F.; KOHLDORF, E.; FARRET, R.; CORDEIRO, S. Forma urbana: que maneiras de compreensão e representação? Revista Brasileira de Estudos Urbanos e Regionais, n.3, p.9-18, 2000. Disponível em: https://rbeur.anpur.org.br/rbeur/article/view/43/29. Acesso em: 05 nov. 2020.

IBGE - Instituto Brasileiro de Geografia e Estatística. Aglomerados Subnormais. 2019. Disponível em: ibge.gov.br/geociencias/organizacao-do-territorio/tipologias-do-territorio/15788-aglomeradossubnormais.html?=\&t=o-que-e. Acesso em: 19 fev. 2021. 
IBGE - Instituto Brasileiro de Geografia e Estatística. Censo Demográfico Brasileiro. Rio de Janeiro: IBGE, 2010.

MARTINS, J. S. Exclusão social e a nova desigualdade. São Paulo: Paulus. 1997.

NASCIMENTO, R. P. B. Geografia, violência e território: uma análise sobre a territorialidade em volta dos homicídios no bairro da Terra Firme, Belém-PA nos anos de 2013 a 2017. Trabalho de Conclusão de Curso (Licenciatura em Geografia). Universidade do Estado do Pará, Curso de Licenciatura Plena em Geografia. Belém, 2019.

NASCIMENTO, R. P. B.; REIS NETTO, R. M.; TOLOSA, T. S. R; CAVALCANTE, C. C. O processo de periferização e violência na baixada belenense: um estudo sobre a territorialidade dos homicídios no bairro da terra firme, Belém-PA entre os anos de 2013 a 2017. In: XIII ENANPEGE, 2019, São Paulo. Anais... São Paulo: ANPEGE, 2019. Disponível em: http://www.enanpege.ggf.br/2019/site/anais2?AREA=24\&impressao. Acesso em: 14 nov. 2020.

OMS - Organização Mundial da Saúde. World report on violence and health: summary. Geneva, World Health Organization, $2002 . \quad$ Disponível em: https://www.paho.org/bra/index.php?option=com_joomlabook\&view=topic\&id=489\#: :text=A\%20 Organiza $\%$ C3\%A7\%C3\%A30\%20Mundial $\% 20$ da $\% 20 \mathrm{Sa} \% \mathrm{C} 3 \%$ BAde,psicol $\%$ C3\%B3gico\%2C\%2 0defici\%C3\%AAncia\%20de\%20desenvolvimento\%20ou Acesso em: 14 nov. 2020.

PEREIRA, M.; RAMALHETE, F. Planeamento e conflitos territoriais: uma leitura na ótica da (in)justiça espacial. Revista Portuguesa de Geografia. FINISTERRA. Vol. 52, n. ${ }^{\circ}$ 104, 2017. Disponível em: https://revistas.rcaap.pt/finisterra/article/view/6972. Acesso em:10 set. 2020.

RIBEIRO, W. O. Entre a metrópole e a cidade média: a complexidade das interações espaciais e das dinâmicas de centralidade da cidade de Castanhal, no nordeste paraense. Geousp - Espaço e Tempo (Online), v. 20, n. 1, p. 115-129. 2016. Disponível em: http://www.revistas.usp.br/geousp/article/view/96710. Acesso em: 16 jul. 2020.

SEGUP. Secretaria de Estado Segurança Pública e Defesa Social. Dados de Crime Violento Letal Intencional. 2019.

SILVA, T. P. Análise espacial e avaliação de vulnerabilidade socioeconômica para os Crimes Violentos Letais Intencionais (CVLI) no Estado de Pernambuco. Geoingá: Revista do Programa de Pós-Graduação em Geografia Maringá, v. 7, n. 2, p. 60-77, 2015. Disponível em: https://periodicos.uem.br/ojs/index.php/Geoinga/article/view/49312. Acesso em: 26 ago. 2020.

SOJA, E. W. En busca de la justicia espacial. Valencia: Tirant Humanidades, 2014.

SOUZA, M. L. ABC do desenvolvimento urbano. Rio de Janeiro: Bertrand Brasil, 2003.

SOUZA, M. L. Mudar a cidade: uma introdução crítica ao planejamento e gestão urbanos. Rio de Janeiro: Bertrand Brasil, 2002.

SPOSITO, M. E. B. A produção do espaço urbano: escalas, diferenças e desigualdades socioespaciais". In: CARLOS, A. F. A.; SOUZA, M. L.; SPOSITO, M. E. B. (Org.). A produção do espaço urbano: agentes e processos, escalas e desafios. São Paulo: Contexto, 2012.

TOPODATA. Banco de Dados Geomorfométricos do Brasil. Disponível em: http://www.dsr.inpe.br/topodata/acesso.php. Acesso em: 02 fev. 2021.

TRINDADE JÚNIOR, S. C. A cidade dispersa: os novos espaços de assentamentos em Belém e a reestruturação metropolitana. 395p. Tese (Doutorado em Geografia) - FFLCH/USP, São Paulo. 1998. 